\title{
Portable Electric Hoist for Effectiveness of Construction of 3rd Floor Houses
}

\author{
M Yusuf Arnol, Nur Ahlina Febriyati \\ Faculty of Engineering, Universitas 45 Surabaya \\ yusuf.arnold@gmail.com,nurahlinaf@gmail.com
}

\begin{abstract}
The development of a city can be measured by the amount of development that has been carried out and its suitability for people needs, which is seen by the increase of demand for Building Construction Permits (IMB certificate) because around $70 \%$ of regional income is derived from levies in this sector. The population density of a residential area is no longer possible developed by horizontally, along with the increase in the needs of dwellings and businesses to meet the needs of the construction of houses and businesses by building them in 3rd floor houses.

Lifting equipment type portable electric hoist is a tool which used to move material from the first floor to the next floor during the construction of 3rd floor houses. The transferred material includes; bricks, ceramics, cement, and other building materials.

This research conducted to analyze the design of a Lifting Equipment for Material type portable electric hoist to increase the effectiveness of the construction of 3rd floor houses. This study uses a direct load testing method by lifting up to the maximum test load or tipping load. Lifting and moving of test loads is determined at an altitude of 5 meters and 12 meters from the ground floor surface.

The results of this research indicates that the five stages load carried out by lifting and moving materials test loads by the design of a portable electric hoist were accepted. Lifting and moving load at sixth floor is rejected because condition of tipping. The rejection of the results from this test became a reference to determine the maximum safe working load for operational design of portable electric hoist only 300 kilograms.
\end{abstract}

Keywords: Lifting equipment, portable electric hoist, 3rd floor building, houses construction

\section{Introduction}

The current lifting equipment outdated and manually operated by human, using a pulley which passed through with a rope tied to the basket then pulled by the worker to move material from the ground floor to the next floor. When operating the manual equipment, the body of the worker and the builder of the building are often looks in a non-ergonomic position, bent over and repeats work movements which can affects not only production output and productivity, but also causes muscle fatigue and disease due to Musculoskeletal Disorders (MSDs). In addition, there are also the potential for failure of equipment use, damage to material being lifted, exposure of workers due to material fall, resulting in accidents due to work and even death which in turn can actually increase the cost and time of completion of a 3rd floor house of construction project. 
Portable manual hoist is a correct equipment which usually used to move material from the first floor to the next floor during the construction of 3rd floor houses. The transferred material includes; bricks, ceramics, cement, and other building materials.

It takes the design of a portable lifting equipment using electricity which easy and safe to operate with the integration of the Quality Function Deployment (QFD) method, because the QFD method is a design process in response to customer needs by define it into a product (goods / service) which produced. The objectives of this research are: 1) Analyzing the design of lifting equipment made to be easier and safer when used in the construction of 3rd floor houses, 2) Identifying the problem of transferring building materials from the ground floor to the next floors in the construction of 3rd floor houses.

The redesign of a portable electric hoist is intended can be used for a long time, reliable, not easily broken or operation failure outside the repair plan that can interfere the progress of the work implementation and cost overruns so that the acceleration and development efficiency can be achieved immediately, increasing economic growth, providing welfare and benefits in all levels of society.

\section{Literature Review}

\subsection{Lifting Equipment for Material}

Hoist is one of the types of Lifting Equipment which is widely used as lifting equipment and transporters in industrial areas, factories, and workshops. This lifting equipment is equipped with wheels and railroad tracks in order to move forward and backward to support its working process. Usually used in the process of lifting and transporting cargo with light to medium weight in open areas with a skeletal structure having a support that stands upright on the ground (https://peraso7.wordpress.com/2014/02/18/selamatdatang-, 2014)

\subsection{3rd Floor Houses}

3rd floor houses are buildings with more than one floor vertically, which are built on the limitations of expensive land urban areas and the high level of demand for space and various types of activities. The more number of floors builted will increase the efficiency of urban land so that the capacity of a city can be increased, but on the other hand it also requires an increasingly complex level of planning and design, which must involve many experts.

3rd floor house buildings are generally divided in two based on the technical requirements of building structures, They are low-rise buildings and high-rise buildings because the structural calculations are more complex. While based on the number of floors, 3rd floor houses are classified into 3; low-rise buildings,3rd floor houses and skyscraper buildings.

\subsection{QFD Method (Quality Function Deployment)}

Quality Function Deployment (QFD) is a methodology to structure systematically the planning and product development process so that customer desires and needs can be determined by evaluating the capabilities of existing products or services in meeting customer needs (Cohen. L, 1995). Is a design process in response to customer needs by translating into a product (goods / services) produced by the company. To improve service quality for customers, a building matrix is used, often known as House of Quality.

Using the QFD method, customer satisfaction data can be obtained in order to direct the organization to improve gaps from design to operational level, so as to provide a structured way to correct weaknesses. 


\subsection{Calculation of Tensile Stress}

Muin, Syamsir A. 1995, the following formula is used for :

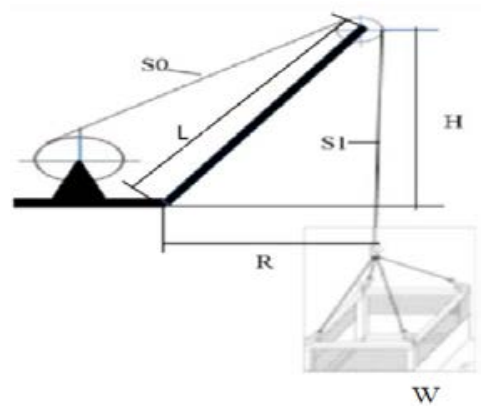

Figure 2.4 Basic Structure of the Hoist (Arnol, 2017)

\subsubsection{Wire Rope Hoist}

$$
\begin{aligned}
& W=S_{0}+S_{1} \\
& S_{1}=W \times \varepsilon
\end{aligned}
$$

Then the maximum limit on steel wire rope is: $Z=S 1 \times(1+\varepsilon)$

$\mathrm{W}=$ Weight raised

$\mathrm{S}_{0}=$ Tensile stress of steel wire rope before passing Pulley

$\mathrm{S}_{1}=$ Tensile stress of steel wire rope after passing Pulley

$\varepsilon=$ Pulley bearing friction constant

\subsubsection{Tipping Load}

Due to the exceeding of lifted load from hoist above, there will be an imbalance so that lifting failure is unavoidable, therefore calculation is needed to determine the Hoist tipping load when it is operated, so that the weight of the lift does not exceed the tipping load, while the formula used is:

$$
\mathrm{W}_{\mathrm{J}}=W \frac{L}{H \times R} \cos \theta \sqrt{R^{2}+H}
$$

$$
\begin{array}{ll}
\mathrm{WJ}_{\mathrm{J}} & =\text { Tipping Load } \\
\mathrm{R} & =\text { Work radius support of the tipping point to lift load } \\
\mathrm{H} & =\text { Distance from Tipping point to the center of the boom pulley } \\
\mathrm{L} & =\text { Boom Length }
\end{array}
$$

In the daily operation for lifting material, the weight (W) lifted should not exceed the tipping load (WJ). 


\section{Research Methodology}

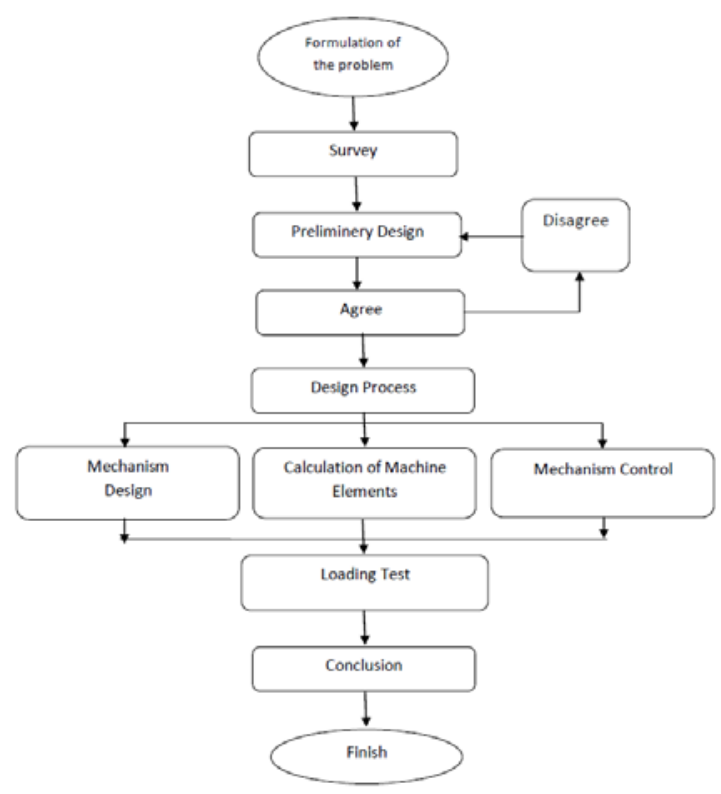

Figure 1 Flowchart of Research Methodology

\section{Results and Discussion}

\subsection{Survey}

Problems in moving of building materials, such as ceramics, bricks, a mixture of materials, cement, gravel, tile, etc. by manually using pulleys and rope with workers to pull the rope so that building materials can be lifted on the next floor. The number of workers for transfer of building materials is more than two people.

\subsection{Preliminary Design}

Lifting of building materials from the ground floor to the top floor by inserting building materials into basket, maximum height of building materials is $2 / 3$ from basket to avoid spills during the implementation of lifting and moving, then the hook at basket is installed to a wire rope hook connected to an electric motor mounted on portable electric hoist. Push the button towards the basket containing building material is lifted and moved, the design is as shown in Figure 4.1

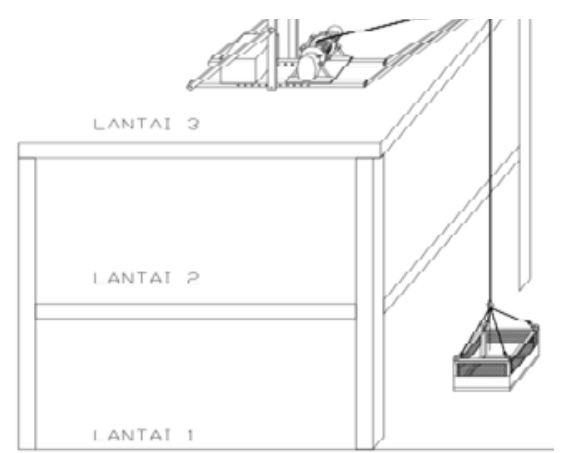

Figure 2 Design of Portable Electric Hoist 


\subsubsection{Calculation of Wire Rope Hoist Tension}

Each movement of lifting the load on the hoist mechanism with a speed of $0.5 \mathrm{~m} / \mathrm{s}$, the load lifted is 300 $\mathrm{kg}$, then the stress on the steel wire rope is :

$$
\begin{gathered}
\mathrm{S}_{1}=\mathrm{W} \times \varepsilon \\
300 \times 0.85=225 \mathrm{~kg}
\end{gathered}
$$

the maximum stress on steel wire rope is : $225 \times(1+0,58)=472 \mathrm{~kg}$

\subsubsection{Calculation of Tipping Load}

Critical conditions in the implementation of construction and transfer of building materials occur tipping load is when the load meet the condition of tipping. The tipping load is :

$$
\begin{aligned}
& \mathrm{W}_{\mathrm{J}}=W \frac{L}{H \times R} \cos \theta \sqrt{R^{2}+H} \\
& \mathrm{~W}_{\mathrm{J}}=300 \times 0,03 \times 51 \\
& \mathrm{~W}_{\mathrm{J}}=459 \mathrm{~kg}
\end{aligned}
$$

\subsection{Proof Load Test}

Load testing conducted to portable electric hoist by several stages of load test, the results in table 4.1

Table. 1 Proof Load Test Result

\begin{tabular}{|c|c|c|c|c|}
\hline Stage/Section & $\begin{array}{c}\text { Load } \\
(\mathrm{kg})\end{array}$ & $\begin{array}{c}\text { Lifting Height } \\
(\mathrm{m})\end{array}$ & $\begin{array}{c}\text { Lifting Speed } \\
(\mathrm{m} / \mathrm{sec})\end{array}$ & Result \\
\hline 1 & 50 & 5 & 0,5 & Accepted \\
\hline 2 & 100 & 5 & 0,5 & Accepted \\
\hline 3 & 150 & 5 & 0,4 & Accepted \\
\hline 4 & 200 & 5 & 0,4 & Accepted \\
\hline 5 & 250 & 5 & 0,4 & Accepted \\
\hline 6 & 300 & 5 & 0,4 & Accepted \\
\hline 7 & 400 & 5 & - & Tipping \\
\hline 8 & 100 & 12 & 0.5 & Accepted \\
\hline 9 & 150 & 12 & 0.5 & Accepted \\
\hline 10 & 200 & 12 & 0.5 & Accepted \\
\hline 11 & 250 & 12 & 0.5 & Accepted \\
\hline 12 & 300 & 12 & 0.5 & Accepted \\
\hline 13 & 400 & 12 & - & Tipping \\
\hline
\end{tabular}

Based on the table 4.1 can be explained if the results of load test that has been conducted with load < $300 \mathrm{~kg}$ portable electric hoist is capable of lifting and moving the test load safely and testing is acceptable, except at a test load of $400 \mathrm{~kg}$ it reach condition of tipping. 


\section{Conclusion}

Based on design analysis and the result of load test from portable electric hoist can be used to lift and move materials such as bricks, ceramics, cement with a maximum load of $300 \mathrm{~kg}$ safely and also reduce the impact of fatigue on workers when lifting and moving building materials.

The design of this portable electric hoist is effectively operated using electricity, so it can simplify and accelerate workers in moving building materials from ground floor to the next floor. Before using a portable electric hoist, workers needs 10 minutes to lifting and moving building materials such as cement weighing $25 \mathrm{~kg}$ by manual handling.

\section{REFERENCE}

[1] ASME B30.16-2012. Overhead Hoist (Underhung), The American Society of Mechanical Engineeners. New York-USA.

[2] Cohen L, 1995 Quality Function Deployment, How to Make QFD Work For You, Addison : Wesley Publishing Company.

[3] Fernando Manurung, 2009, Perancangan Overhead Travelling Crane dengan Kapasitas Angkat 120 ton dan Perhitungan Bahan Crane Pada Pembangkit Listrik Tenaga Air, Departemen Teknik Mesin, Fakultas Teknik, Universitas Sumatera Utara, Medan.

[4] http://artikel-tekniksipil.blogspot.co.id

[5] https://www.bing.com/images

[6] https://peraso7.word press.com/2014/02/18/selamat-datang-, 2014

[7] International Ergonomics Association (IEA), 2015, http://www.iea.cc (accessed on February $\left.9^{\text {th }} 2015\right)$.

[8] Kroemer Karl, Kroemer Henrike, Kroemer Katrin - Elbert, 2001, Ergonomics - How To Design For Ease And Efficiency, Prentice Hall International Series in Industrial \& System Engineering, W.J. Fabrycky \& J.H.Mize, editor. , Second Edition, New Jersey 07458.

[9] Muin, Syamsir, 1995, Pesawat-Pesawat Pengangkat, Edisi I, Penerbit Raja Grafindo Persada, Jakarta.

[10] M. Tokar, B. Arzensek, 2000, Failure of Crane Wire Rope. Engineering Failure Analysis 9 (2002) 227-223

[11] Nurmianto, Eko, 2004, Ergonomi, Konsep Dasar Dan Aplikasinya, Guna Widya Surabaya, edisi kedua, ISBN : 979-545-007-7. Surabaya.

[12] Tjahjani, Wignjosoebroto dan Ciptomulyono, 2011. Perancangan Sistem Pengolahan Sampah Organik Dengan Inovasi Komposter Yang Ergonomis Menggunakan Metode Quality Function Deployment (QFD), Prosiding Seminar Nasional Manajemen Teknologi VIII, Program Studi MMT ITS, Surabaya.

[13] Rodenko, N., 1964., Material Handing Equipment, peace Publisher.Moscow 